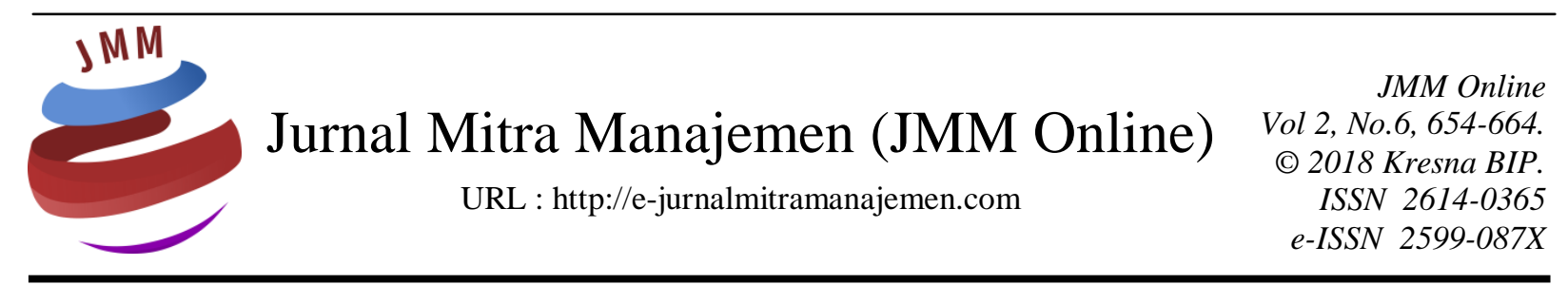

\title{
ANALISIS KELAYAKAN USAHA PENGOLAHAN IKAN ASAP DI KECAMATAN WAWOTOBI KABUPATEN KONAWE
}

\author{
Endang Sumiratin ${ }^{1)}$, Sarty Syarbiah ${ }^{2)}$ \\ Universitas Lakidende
}

INFORMASI ARTIKEL

Dikirim : 30 Oktober 2018

Revisi pertama : 17 November 2018

Diterima : 20 November 2018

Tersedia online : 01 Desember 2018

Kata Kunci : Analisis Pendapatan, Analisis Kelayakan dan Usaha

Pengolah Ikan Asap

Email : eenendangs@gmail.com

\section{ABSTRAK}

Kecamatan Wawotobi Kabupaten Konawe merupakan salah satu daerah para pelaku usaha pengolah ikan asap dalam menjalankan usahanya. Pelaku usaha pengolah ikan asap di Kecamatan Wawotobi adalah industri kecil atau industri Rumah Tangga dimana modal yang mereka peroleh adalah modal sendiri, dengan kondisi sosial ekonomi yang berbeda-beda, sehingga pendapatan yang diperoleh pedagang satu dengan pedagang lainnya berbeda-beda pula, baik dari segi usaha maupun dari segi produksi yang diperoleh.

Penentuan lokasi penelitian dilakukan secara langsung (purposive). Variabel yang diamati dalam penelitian ini adalah :Identitas responden meliputi : umur, pendidikan formal, pengalaman berusaha dan jumlah tanggungan keluarga. Pendapatan meliputi : besarnya penerimaan dan biaya usaha yang dikeluarkan.

Berdasarkan hasil penelitian diketahui bahwa : 1 . Penerimaan rata-rata usaha pengolahan ikan asap yang dilakukan di Kecamatan Wawotobi Kabupaten Konawe rata-rata sebesar Rp. 20.336.646,- setiap produksi dalam 1 bulan, dan biaya rata-rata yang dikeluarkan dalam usaha pembuatan ikan asap sebesar Rp. 15.247.098,- serta pendapatan rata-rata yang diperoleh sebesar Rp.5.089.548,-. 2. Usaha pengolahan ikan asap layak dikembangkan karena mempunyai $R / C=1,3$ artinya setiap penggunaan biaya Rp. 1.000,- maka akan diperoleh penerimaan Rp. 333, - layak diusahakan/menguntungkan 


\section{PENDAHULUAN \\ Latar Belakang}

Pada konsep produksi pengolahan makanan adalah anggapan pemasar yang berorientasi kepada proses olahan bahwa konsumen hanya akan membeli makanan yang murah dan dan dengan demikian fokus kegiatan harus dilakukan adalah efisiensi biaya (produksi dan distribusi) agar dapat menjual hasil olahan makanan dengan murah kepada konsumen ada anggapan bahwa konsumen lebih menghendaki makanan yang enak dan bergizi. Dengan demikian tujuan usaha pengolah ikan asap ini adalah kualitas ikan yang baik, karena banyaknya pesaing-pesaing pengusaha pengolah ikan asap berusaha untuk dapat memenuhi dan memuaskan pelanggan. Adapun makan adalah kebutuhan utama bagi seluruh makhluk hidup.

Kecamatan Wawotobi Kabupaten Konawe merupakan salah satu daerah para pelaku usaha pengolah ikan asap dalam menjalankan usahanya. Pelaku usaha pengolah ikan asap di Kecamatan Wawotobi adalah industri kecil atau industri Rumah Tangga dimana modal yang mereka peroleh adalah modal sendiri, dengan kondisi sosial ekonomi yang berbeda-beda, sehingga pendapatan yang diperoleh pedagang satu dengan pedagang lainnya berbeda-beda pula, baik dari segi usaha maupun dari segi produksi yang diperoleh. Dari kondisi uraian diatas penulis merasa tertarik untuk mengkaji lebih jauh tentang pendapatan yang diperoleh dari usaha tersebut.

\section{Rumusan Masalah}

Adapun rumusan masalah yang diangkat dalam penelitian ini adalah :

1. Seberapa besar biaya yang dikeluarkan dalam usaha pengasapan ikan

2. Seberapa besar penerimaan yang diterima oleh pengusaha ikan asap

3. Seberapa besar pendapatan yang diperoleh oleh pengusaha ikan asap

4. Apakah usaha pembuatan ikan asap di Kecamatan Wawotobi Kabupaten Konawe sudah dikatakan layak.

\section{Tujuan Penelitian}

Adapun tujuan yang ingin dicapai dalam penelitian ini adalah :

1. Untuk mengetahui seberapa besar biaya yang dikeluarkan dalam usaha pengasapan ikan asap

2. Untuk mengetahui seberapa besar penerimaan yang diterima oleh pengusaha ikan asap

3. Untuk mengetahui seberapa besar pendapatan yang diperoleh pengusaha ikan

4. Untuk menganalisa kelayakan usaha pembuatan ikan asap di Kecamatan Wawotobi Kabupaten Konawe

\section{KAJIAN PUSTAKA}

Penerimaan menurut Hernanto (2007), menyatakan bahwa penerimaan usahatani adalah penerimaan dari semua usahatani meliputi jumlah penambahan inventaris, nilai penjualan hasil, dan nilai yang dikonsumsi. Penerimaan usahatani dapat dibedakan menjadi dua, yaitu penerimaan bersih usahatani dan penerimaan kotor usahatani (gross income). 
Penerimaan bersih usaha tani adalah merupakan selisih antara penerimaan kotor usahatani dengan pengeluaran total usahatani. Pengeluaran total usahatani adalah nilai semua masukan yang habis terpakai dalam proses produksi, tidak termasuk tenaga kerja dalam keluarga petani. Sedangkan penerimaan kotor usahatani adalah nilai total produksi usahatani dalam jangka waktu tertentu baik yang dijual maupun tidak dijual. Penerimaan usahatani dipengaruhi oleh produksi fisik yang dihasilkan, dimana produksi fisik adalah hasil fisik yang diperoleh dalam suatu proses produksi dalam kegiatan usahatani selama satu musim tanam. Penerimaan usahatani akan meningkat jika produksi yang dihasilkan bertambah dan sebaliknya akan menurun bila produksi yang dihasilkan berkurang. Disamping itu, bertambah atau berkurangnya produksi juga dipengaruhi oleh tingkat penggunaan input pertanian (Soekartawi, 2002).

Biaya adalah pengeluaran dalam proses produksi yang dapat dihindarkan. Hal ini berarti bahwa proses produksi harus dijalankan secara efisien dengan menghindarkan pemborosan. Hasil akhir biaya produksi adalah produk atau output, produksi dalam pertanian atau lainnya dapat bervariasi antara lain disebabkan karena perbedaan kualitas dimana kualitas yang baik dihasilkan oleh proses produksi yang baik dan begitu pula sebaliknya, kualitas produksi menjadi kurang baik bila usaha tersebut dilaksanakan dengan kurang baik (Soekartawi, 2002). Biaya mempunyai peranan penting dalam pengambilan keputusan usahatani. Besarnya biaya yang diperlukan untuk memproduksi sesuatu menentukan besarnya harga pokok dari harga yang dihasilkan. Menurut Putu Rustami, I Ketut Kriya \& Wayan Cipta (2014), biaya produksi adalah semua pengeluaran yang harus dikeluarkan produsen untuk memperoleh faktor-faktor produksi dengan bahan-bahan penunjang lainnya yang akan didaya gunakan agar produk-produk tertentu yang telah direncanakan dapat terwujud dengan baik.

\section{Pengolahan Ikan Asap}

\section{Pemilihan Bahan Ikan}

Semua jenis ikan pada dasarnya dapat dipilih untuk pengolahan menjadi ikan asap. Namun disarankan ada beberapa ikan yang mempunyai tekstur dan aroma rasa yang bagus, ikan laut seperti ikan cakalang, tembang dan layang yang enak untuk diasapkan.

Klasifikasi ikan cakalang, tembang dan layang adalah sebagai berikut :

a. Ikan cakalang

Cakalang adalah ikan pelagis yang merupakan perenang cepat (good swimmer) dan mempunyai sifat rakus (varancious). Ikan ini melakukan migrasi jarak jauh dan hidup bergerombol dalam ukuran besar. Bentuk tubuhnya digolongkan dalam bentuk torpedo, yaitu badan fusiform, bagian kepala sangat tebal, ramping dan kuat kearah ekor dan sedikit pipih pada bagian samping. Sistematika ikan cakalng adalah sebagai berikut :
Phylum : Vertebrata
Sub phylum : Craniata
Class : :Teleostomi
Sub class : Actinopterygii
Ordo : Ferciformes 
Family : : Scombridae

Genus : : Katsuwonus

Species : Katsuwonus pelamis

Gambar ikan cakalang adalah sebagai berikut :

b. Ikan Tembang

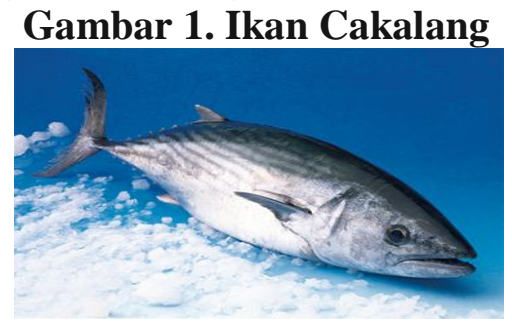

Ikan tembang (Sardinella fimbriata), mempunyai bentuk tubuh yang memanjang, badan tertutup sisik sampai di kepala, kecuali bagian moncong sebelah depan. Mulut agak lebar dengan gigi yang lemah, tanda khususnya adalah sepasang gurat sisi (linea lateralis) membentuk garis yang tak terputusputus memanjang mulai dari ujung ekor sampai di ujung tutup insang. Ikan tembang (Sardinella fimbriata) memiliki cirri-ciri bentuk tubuh langsing memanjang dan tidak begitu kompres. Sirip punggung berjari-jari lemah 30-35 dan punggung jari-jari keras 8 , sirip dubur terdiri dari dua jari-jari keras bergabung dengan 26-30 jari-jari lemah. Kebanyakan ikan ini berwarna agak cerah yaitu warna tubuhnya yang bertingkat, di bagian dorsal berwarna biru kemudian bagian sisik keperak-perakan, dan putih bagian perut. Panjang tubuh ikan ini biasanya mencapai $21 \mathrm{~cm}$. Sistematika ikan tembang adalah sebagai berikut :

Kingdom = Animalia

Phylum $=$ Chordata

Class $=$ Actinopterygii

Ordo $=$ Clupeiformes

Family = Clupeidae

Genus = Sardinella

Spesies = Sardinella fimbriata

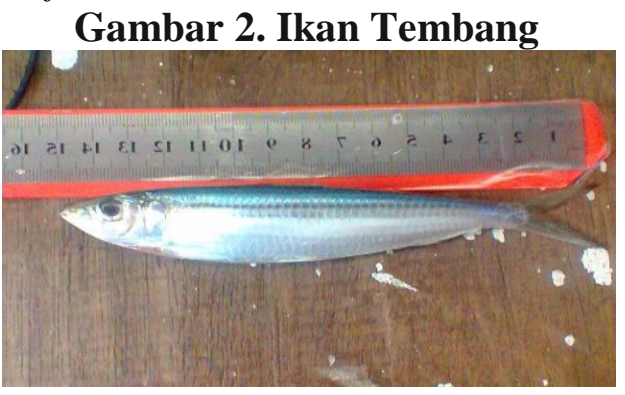

c. Ikan Layang

Ikan layang (Decapterus spp) merupakan salah satu komunitas perikanan pelagis kecil yang penting di Indonesia. Ikan yang tergolong suku Carangidae ini bisa hidup bergerombol . Ukurannya sekitar 15 centimeter 
meskipun ada pula yang bisa mencapai 25 centimeter . Ciri khas yang sering dijumpai pada ikan layang ialah terdapatnya sirip kecil ( finlet) di belakang sirip punggung dan sirip dubur dan terdapat sisik berlinginyang tebal (lateral scute) pada bagian garis sisi (lateral line). Diskripsi ikan layang biasa (Decapterus russelli), badan memanjang, agak gepeng. Dua sirip punggung. Sirip punggung pertama berjari-jari keras 9 (1 meniarap +8 biasa), sirip punggung kedua berjarijari keras 1 dan 30-32 lemah. Sirip dubur berjari-jari keras 2 (lepas) dan 1 bergabung dengan 22-27 jari sirip lemah. Baik di belakang sirip punggung kedua dan dubur terdapat 1 jari-jari sirip tambahan (finlet) termasuk pemakan plankton, diatomae, chaetognatha, copepoda, udangudangan larva-larva ikan,juga telur-telur ikan teri (Stolephorus sp,). Hidup di perairan lepas pantai, kadar garam tinggi membentuk gerombolan besar. Dapat mencapai panjang $30 \mathrm{~cm}$, umumnya 20-25 cm. Warna: biru kehijauan, hijau pupus bagian atas, putih perak bagian bawah. Sirip siripnya abu-abu kekuningan atau kuning pucat. Satu totol hitam terdapat pada tepian atas penutup insang. Klasifikasi sistematika ikan layang adalah sebagai berikut :

$\begin{array}{ll}\text { Phyllum } & \text { : Chordata } \\ \text { Kelas } & : \text { Pisces } \\ \text { Sub kelas } & : \text { Teleostei } \\ \text { Ordo } & : \text { Percomorphi } \\ \text { Divisi } & : \text { Perciformes } \\ \text { Sub divisi } & : \text { Carangi } \\ \text { Familia } & : \text { Carangidae } \\ \text { Genus } & : \text { Decapterus } \\ \text { Spesies } & : \text { Decaptersus russelli } \\ & \text { 2. Decapterus macrosoma }\end{array}$

Gambar 3. Ikan Layang

2. Tempat Pengasapan

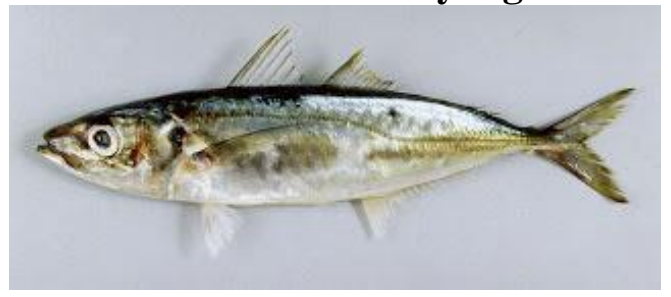

Untuk tempat pengasapan dipersiapkan tempat tersendiri yang terbuat dari batu bata dengan ukuran $3 \mathrm{~m}: 2 \mathrm{~m}: 1,5 \mathrm{~m}$ (tinggi : lebar : panjang). Tempat pengasapan ini sebaiknya dilengkapi dengan cerobong asap untuk memudahkan mengeluarkan asap. Selain itu juga perlu disiapkan bambu yang nantinya digunakan untuk tusuk ikan. Jarak antara ikan dengan api diharapkan tidak terlalu dekat karena akan menyebabkan ikan menjadi gosong.

a. Bahan Bakar

Untuk proses pengasapan digunakan bahan bakar dari tempurung kelapa, sedangkan sabut kelapa berfungsi untuk menghilangkan bakteri pengurai. Baru-baru ini arang dari tempurung kelapa mempunyai nilai jual yg 
cukup tinggi dan aroma khas tempurng kelapa banyak di gemari para penikmat kuliner.

b. Proses Pengasapan

Ikan dibersihkan dan dibuang insang dan isi perutnya terlebih dahulu sebelum diasapi, bahan ikan kemudian direndam kedalam larutan air garam dan jeruk nipis selama kurang lebih 20 menit untuk mengurangi bau amis. Persiapkan pembakaran dengan membakar tempurung kelapa dan sabut kelapa dalam tempat pengasapan. Jaga suhu pengasapan antara $70-100{ }^{\circ} \mathrm{C}$. Kemudian masukkan ikan yang sudah disiapkan. Secara berkala dibalik setiap 2 menit sekali sampe matang. Setelah selesai ikan dimasukkan kedalam platik kemasan dan divacum agar tetap steril. Setelah panas dari proses pengasapan hilang, simpan ikan asap kedalam freezer agar ikan lebih tahan lama sebelum laku dipasarkan.

Kelayakan Usaha Selisih antara pendapatan kotor usahatani dan pengeluaran total usahatani disebut pendapatan bersih petani (net farm income). Pendapatan bersih usahatani menyangkut imbalan yang diperoleh keluarga petani dari penggunaan faktorfaktor produksi kerja, pengelolaan, dan modal milik sendiri atau modal yang diinvestasikan kedalam usahatani. Karena itu ia merupakan ukuran keuntungan usahatani yang dapat dipakai untuk membandingkan penampilan beberapa usahatani. Karena modal dapat dihitung sebagai pengeluaran, maka perbandingan tidak dikacaukan oleh perbedaan tingkat utang. Bagaimanapun juga pendapatan bersih usahatani merupakan langkah antara untuk menghitung ukuran-ukuran keuntungan lainnya yang mampu memberikan penjelasan lebih banyak (Soekartawi, dkk. 2002)

Dengan cara mengurangi nilai berbagai komponen sumberdaya dari pendapatan bersih usahatani, maka pengembalian hasil yang diperoleh komponen lainnya dapat dihitung. Mengukur dan menilai faktor produksi pengelolaan tidak mudah. Dalam menilai keberhasilan usahatani diperlukan evaluasi dari sudut pandang ekonomis yaitu biaya dan pendapatan, kelayakan usaha, suatu usaha dikatakan layak jika $\mathrm{R} / \mathrm{C}$ ratio $>1$

\section{METODE PENELITIAN}

Populasi dalam penelitian ini adalah seluruh pengusaha ikan asap yang berjumlah 23 orang. Teknik pengambilan sampel dilakukan dengan cara sensus yaitu dengan mengambil seluruh jumlah populasi yang ada di Kecamatan Wawotobi Kabupaten Konawe. Dalam penelitian ini, jenis data yang digunakan adalah data kualitatif dan kuantitatif.

Sedangkan sumber data yang digunakan adalah : a. Data primer yaitu data yang diperoleh langsung dari pengusaha ikan pelaku bisnis hasil perikanan melalui wawancara dan kuesioner, jenis usaha, harga beli, harga jual yang relevan, mengenai pertanyaan dan pernyataan dengan kebutuhan penelitian. b. Data sekunder adalah data yang diperoleh melalui cacatan yang diarsipkan oleh instansi terkait, dalam hal ini kepala pasar, berupa data jenis usaha yang dijalankan oleh pedagang sebagai penjual aneka olahan makanan dan data penunjang yang relevan dengan penelitian ini.

Variabel yang diamati dalam penelitian ini adalah : 1. Identitas responden meliputi : umur, pendidikan formal,pengalaman berusaha dan jumlah tanggungan 
keluarga. 2. Pendapatan meliputi : besarnya penerimaan dan biaya usaha yang dikeluarkan.

\section{Teknik Analisis Data}

1. Biaya

Dimana :

$$
\mathrm{TC}=\mathrm{TFC}+\mathrm{TVC} \quad(\text { Ayub, 2014 })
$$

$\mathrm{TC}=$ Total cost/biaya total $(\mathrm{Rp})$

$\mathrm{TFC}=$ Total Biaya Tetap $(\mathrm{Rp})$

$\mathrm{TVC}=$ Total Biaya Variabel $(\mathrm{Rp})$

2. Penerimaan

$$
\mathrm{TR}=\mathrm{P} \times \mathrm{Q} \quad(\text { Ayub, } 2014)
$$

Dimana :

$$
\begin{aligned}
\mathrm{TR} & =\text { Total revenue/penerimaan total }(\mathrm{Rp}) \\
\mathrm{P} & =\operatorname{Harga} \text { Produksi }(\mathrm{Rp}) \\
\mathrm{Q} & =\text { Jumlah Produk }(\mathrm{Rp})
\end{aligned}
$$

3. Pendapatan

Dimana :

$$
\mathrm{I}=\mathrm{TR}-\mathrm{TC} \quad(\text { Ayub, } 2014)
$$

$\mathrm{I}=$ Income/pendapatan usahatani $(\mathrm{Rp})$

$\mathrm{TR}=$ Total revenue/penerimaan total $(\mathrm{Rp})$

$\mathrm{TC}=$ Total cost/biaya total $(\mathrm{Rp})$

4. Kelayakan Usaha

$$
\mathrm{R} / \mathrm{C} \text { ratio }=\frac{\text { Total revenue }(\mathrm{TR})}{\text { Total cost }(\mathrm{TC})} \quad \text { (Ayub, 2014) }
$$

Dimana :

$\mathrm{R} / \mathrm{C}$ ratio $=$ Revenue cost ratio

$\mathrm{TR}=$ Total revenue $(\mathrm{TR})$

TC $=$ Total cost (TC)

Dengan Kriteria :

1. $\mathrm{R} / \mathrm{C}$ ratio $>1$ maka efisien (menguntungkan) layak untuk diusahakan.

2. $\mathrm{R} / \mathrm{C}$ ratio $=1$ maka impas (break event).

3. $\mathrm{R} / \mathrm{C}$ ratio < 1 maka belum efisisen (merugikan)/ tidak layak diusahakan. 


\section{HASIL PENELITIAN DAN PEMBAHASAN}

\section{Analisis Pendapatan Ikan Asap}

1. Produksi Usaha ikan asap

Menurut Soetriono (2006) menyatakan bahwa untuk >> pengolah ikan asap jumlah produksi (output) merupakan salah satu yang menentukan besarnya penerimaan atau usaha. Besarnya penerimaan dari hasil mengolah ikan asap diperhitungkan dengan cara mengalihkan hasil produksi pengolah ikan asap dengan masing-masing harganya perkilogram pada saat produksi.

Tabel 1. Jumlah Responden Berdasarkan Hasil Produksi Ikan Cakalang Oleh Pengusaha Ikan Asap di Kecamatan Wawotobi

\begin{tabular}{|c|c|c|c|}
\hline No & Produksi (Ekor) & Jumlah Responden & Persentase (\%) \\
\hline 1. & $\leq 1.546$ (Rendah) & 11 & 47,83 \\
\hline 2. & $>1.546$ (Tinggi) & 12 & 52,17 \\
\hline & Jumlah & 23 & 100 \\
\hline
\end{tabular}

Sumber : Hasil Penelitian diolah, (2016)

Dari Tabel diatas menunjukkan bahwa produksi terendah responden yaitu $\leq$ 1.546 dengan jumlah responden sebanyak 11 orang dengan rata-rata 47,83 \%, dan produksi yang terbanyak responden yaitu $>1.546$ dengan jumlah responden yaitu 12 orang dengan rata-rata 52,17\%.

Tabel 2. Jumlah Responden Berdasarkan Hasil Produksi Ikan Tembang oleh Pengusaha Ikan Asap di Kecamatan Wawotobi

\begin{tabular}{|c|c|c|c|}
\hline No & Produksi (Ekor) & Jumlah Responden & Persentase $(\%)$ \\
\hline 1. & $\leq 5.804$ & 9 & 39,13 \\
\hline 2. & $>5.804$ & 14 & 60,87 \\
\hline \multicolumn{2}{|r|}{ Jumlah } & 23 & 100 \\
\hline
\end{tabular}

Sumber : Hasil Penelitian diolah, (2016)

Dari tabel menunjukkan bahwa produksi terendah responden yaitu $>5.804$ dengan jumlah responden sebanyak 14 orang dengan rata-rata $60,87 \%$, dan produksi yang terbanyak responden yaitu $\leq 5.804$ dengan jumlah responden yaitu 9 orang dengan rata-rata 39,13\%.

Tabel 3. Jumlah Responden Berdasarkan Hasil Produksi Ikan Layang oleh Pengusaha Ikan Asap di Kecamatan Wawotobi

\begin{tabular}{|c|c|c|c|}
\hline No & Produksi (Ekor) & Jumlah Responden & Persentase (\%) \\
\hline 1. & $\leq 3.607$ & 11 & 47,83 \\
\hline 2. & $>3.607$ & 12 & 52,17 \\
\hline \multicolumn{2}{|r|}{ Jumlah } & 23 & 100 \\
\hline
\end{tabular}

Sumber : Hasil Penelitian diolah, (2016)

Tabel tersebut menunjukkan bahwa produksi terendah responden yaitu $\leq$ 3.607 dengan jumlah responden sebanyak 11 orang dengan rata-rata 47,83\%, dan produksi yang terbanyak responden yaitu > 3.607 dengan jumlah responden yaitu 12 orang dengan rata-rata $52,17 \%$. 


\section{Penerimaan}

Penerimaan adalah jumlah produksi dikalikan dengan jumlah harga jual yang berlaku pada saat penelitian. Besar kecilnya penerimaan dari usaha pengolah ikan asap ditentukan oleh besar kecilnya jumlah produksi yang dihasilkan dan harga jual produk tersebut. Semakin tinggi harga jual akan semakin tinggi penerimaan yang diperoleh pengusaha.

Tabel 4. Jumlah Responden Berdasarkan Hasil Penerimaan Pengusaha di Kecamatan Wawotobi

\begin{tabular}{|c|c|c|c|}
\hline No & Penerimaan (Rp) & Jumlah Responden & Persentase (\%) \\
\hline 1. & $\leq 20.336 .646,-($ Rendah $)$ & 11 & 47,83 \\
\hline 2. & $>20.336 .646,-$ (Tinggi) & 12 & 52,17 \\
\hline \multicolumn{2}{|r|}{ Jumlah } & 23 & 100 \\
\hline
\end{tabular}

Sumber : Hasil Penelitian diolah, (2016)

Tabel 4 menunjukkan bahwa penerimaan terendah responden yaitu $\leq \mathrm{Rp}$. 20.336.646,- dengan jumlah responden sebanyak 11 orang dengan rata-rata 47,83\%, dan penerimaan yang terbanyak responden yaitu > Rp. 20.336.646,- dengan jumlah responden yaitu 12 orang dengan rata-rata $52,17 \%$.

3. Biaya Variabel

Penggunaan biaya yang baik tentu akan dapat meningkatkan produksi dan pendapatan sehingga dapat meningkatkan taraf hidup pengusaha.

Ikan asap yang digunakan pengusaha sebaiknya dari ikan asap yang baik atau hasil sortiran sehingga dapat meningkatkan produksi yang akan diterima oleh pengusaha.

Tabel 5. Biaya Variabel dalam Satu Kali Proses Produksi (1 Bulan)

\begin{tabular}{|c|c|c|c|}
\hline No & Biaya Variabel (Rp) & Jumlah Responden & Persentase (\%) \\
\hline 1. & $\leq 15.221 .913,-($ Rendah) & 11 & 47,83 \\
2. & $>15.221 .913,-$ (Tinggi) & 12 & 52,17 \\
\hline \multicolumn{2}{|c|}{ Jumlah } & $\mathbf{2 3}$ & $\mathbf{1 0 0}$ \\
\hline
\end{tabular}

Sumber : Hasil Penelitian diolah, (2016)

Tabel diatas terlihat pengusaha responden yang menggunakan biaya yang paling banyak adalah 12 orang $(52,17 \%)$ pengusaha responden yaitu > Rp. 15.221.913,- dan yang terendah adalah sebanyak 11 orang $(47,83 \%)$ pengusaha responden yaitu $\leq$ Rp. 15.221.913,-.

4. Biaya Tetap

Tabel 6. Peralatan yang digunakan dalam Kegiatan Usaha Pembuatan Ikan Asap

\begin{tabular}{|c|c|c|c|}
\hline No. & Biaya Tetap (Rp) & Jumlah Responden & Persentase (\%) \\
\hline 1. & $\leq 25.185,-($ Rendah) & 12 & 52,17 \\
2. & $>25.185,-($ Tinggi) & 11 & 47,83 \\
\hline \multicolumn{2}{|c|}{ Jumlah } & $\mathbf{2 3}$ & $\mathbf{1 0 0}$ \\
\hline
\end{tabular}

Sumber : Hasil Penelitian diolah, (2016) 
Tabel tersebut terlihat pengusaha responden yang menggunakan biaya adalah 11 orang $(47,83 \%)$ pengusaha responden yaitu > Rp. 25.185 ,- dan sebanyak 12 orang $(52,17 \%)$ pengusaha responden yaitu $\leq$ Rp. $25.185,-$.

5. Pendapatan

Besar kecilnya pendapatan yang akan diterima pengusaha tergantung dari bagaimana kemapuan pengusaha dalam mengorganisir faktor-faktor produksi. Besarnya tingkat pendapatan usaha yang diperoleh merupakan ukuran keberhasilan usaha yang dikelolanya dan juga menggambarkan kemajuan

Tabel 7. Jumlah Responden Berdasarkan Pendapatan Pengusaha di Kelurahan Hopa-Hopa Kecamatan Wawotobi

\begin{tabular}{|c|c|c|c|}
\hline No & Pendapatan (Rp) & Jumlah Responden & Persentase $(\%)$ \\
\hline 1. & $<5.089 .548,-($ Rendah $)$ & 11 & 47.83 \\
\hline 2. & $>$ 5. 089.548,-(Tinggi) & 12 & 52,17 \\
\hline \multicolumn{2}{|r|}{ Jumlah } & 23 & 100 \\
\hline
\end{tabular}

Sumber : Hasil Penelitian diolah, (2016)

Tabel tersebut menunjukkan bahwa pendapatan terendah responden yaitu $\leq$ Rp. 5. 089.548,- dengan jumlah responden sebanyak 13 orang dengan rata-rata 47,83 $\%$, dan pendapatan yang terbanyak responden yaitu > Rp. 5. 089.548,- dengan jumlah responden yaitu 10 orang dengan rata-rata $52,17 \%$.

\section{Analisis Kelayakan}

Analisis ini digunakan untuk mengetahui kelayakan usaha pengolah ikan asap mengetahui efisiensi dari penggunaan biaya sarana produksi usaha oleh pengusaha responden.

Untuk mengetahui kelayakan usaha pengolah ikan asap dapat diuraikan dalam rumus :

$$
\begin{aligned}
\text { R/C ratio } & =\frac{\operatorname{Revenue~}(\mathbf{R})}{\text { Cost }(\mathbf{C})} \\
& =\frac{\text { Rp. } 20.336 .646,-}{\text { Rp. 15.247.098,-- }} \\
& =1.333 .804,- \\
& =1,3
\end{aligned}
$$

Berdasarkan hasil analisis data diketahui total penerimaan (revenue) rata-rata per usaha pengolah ikan asap sebesar Rp. 20.336.646,- per usaha sedangkan rata-rata per usaha sebesar Rp. 15.247.098,- sehingga diperoleh R/C sebesar 1,3.

Nilai R/ C ratio lebih besar dari satu, hal ini berarti bahwa dalam usaha pengolah ikan asap yang dilakukan di Kelurahan Hopa-Hopa Kecamatan Wawotobi adalah efisien dan setiap Rp. 1.000.000,- rupiah biaya yang dikorbankan dalam usaha pengolah ikan asap oleh pengusaha responden menghasilkan penerimaan Rp. 20.336.646,- sehingga responden mendapat pendapatan sebesar Rp. 1.333.804,- setiap pengeluaran Rp 1.000.000,- dalam usahanya. Dilihat dari selisih penerimaan dan biaya 
yang dikeluarkan menunjukkan bahwa usaha pengolah ikan asap di Kelurahan HopaHopa Kecamatan Wawotobi Kabupaten Konawe memberikan pendapatan yang besar dengan rata-rata pendapatan memperoleh sebanyak Rp. 5.089.548,-.

\section{KESIMPULAN DAN SARAN \\ Kesimpulan}

Berdasarkan pembahasan hasil penelitian dapat disimpulkan bahwa Penerimaan rata-rata usaha pengolahan ikan asap yang dilakukan di Kecamatan Wawotobi Kabupaten Konawe rata-rata sebesar Rp. 20.336.646,- setiap produksi dalam 1 bulan, dan biaya rata-rata yang dikeluarkan dalam usaha pembuatan ikan asap sebesar Rp. 15.247.098,- serta pendapatan rata-rata yang diperoleh sebesar Rp. 5.089.548,--

Usaha pengolahan ikan asap layak dikembangkan karena mempunyai $\mathrm{R} / \mathrm{C}=1,3$ artinya setiap penggunaan biaya Rp. 1.000.000,- maka akan diperoleh pendapatan Rp. 1.333.804,- layak diusahakan/ menguntungkan.

\section{Saran}

Berdasarkan kesimpulan maka penulis menyarankan :

1. Khususnya pengusaha pengolah ikan asap di Kelurahan Hopa-Hopa Kecamatan Wawotobi agar mengalokasikan produksi dengan lebih efisien untuk meningkatkan pendapatan usahanya.

2. Disarankan agar petani terus menyempurnakan penerapan teknologi agar produksi dan pendapatan yang diperoleh lebih meningkat lagi.

3. Perlu adanya pembinaan dalam bentuk penyuluhan dari instansi yang terkait yang lebih intensif lagi tentang tata cara pengolahan hasil perikanan yang lebih baik khususnya usaha pengolahan ikan asap.

4. Perlu adanya pengembangan pengolahan ikan asap di Kelurahan Hopa-Hopa Kecamatan Wawotobi Kabupaten Konawe.

\section{DAFTAR PUSTAKA}

Hernanto, F. 2007. Ilmu Usahatani. Jakarta: Penebar Swadaya.

Putu Rustami, I Ketut Kriya \& Wayan Cipta. 2014. Pengaruh Biaya Produksi, Biaya Promosi, dan Volume Penjualan terhadap Laba. e-Journal Bisma. Universitas Pendidikan Ganesha Jurusan Manajemen, Buleleng, Bali.

Soekartawi. 2002. Analisis Usahatani. Jakarta: Universitas Indonesia

Soetriono, 2006, Analisis Finansial dan Analisis Ekonomi, Daya Saing dalam Tinjauan Analisis. Malang: Bayu Media 